\title{
Substrate and quality mangosteen seedlings
}

\author{
Gedeon Almeida Gomes Júnior ${ }^{1}$, Rafaela Alves Pereira ${ }^{2}$, Danillo José dos Santos ${ }^{3}$, \\ George Andrade Sodré ${ }^{4}$, Eduardo Gross ${ }^{5}$
}

\begin{abstract}
An obstacle to the production of mangosteen seedlings (Garcinia mangostana L.) is the long nursery time of approximately two years. Among other factors, the identification of a suitable substrate for seedling production from this species is a preponderant factor to reduce nursery time. This study aimed to evaluate the growth of seminal mangosteen seedlings grown in four different substrate compositions. Growth rate was determined using the following variables: stem diameter, plant height, stem dry mass, leaf dry mass, shoot dry mass, root dry mass, total dry mass and Dickson Quality Index (DQI). The substrate S1 (sphagnum turf and vermiculite) was superior to substrates S2 (pinus bark and vermiculite), S3 (pinus bark and coconut fiber) and S4 (soil) in all evaluated parameters. The principal component analysis separated the treatments into three response groups, in which S1 exerted the greatest influence on the growth variables, concluding that this one of the substrates tested was the most adequate for the formation of mangosteen seedlings.

Index terms: Garcinia mangostana L., DQI, rooting
\end{abstract}

\section{Susbtrato e qualidade de mudas de mangostanzeiro}

Corresponding author: egross@uesc.br

Received: February 17, 2019 Accepted: February 26, 2019

Copyright: All the contents of this journal, except where otherwise noted, is licensed under a Creative Commons Attribution License.
Resumo- Um entrave para a produção de mudas do mangostanzeiro (Garcinia mangostana L.) é o prolongado tempo de viveiro de aproximadamente dois anos. Dentre outros fatores, a identificação de um substrato adequado à produção de mudas dessa espécie é fator preponderante para reduzir o tempo de viveiro. Este estudo objetivou avaliar o crescimento de mudas seminais de mangostanzeiro cultivadas em quatro diferentes composições de substrato. A avaliação do crescimento foi realizada por meio das variáveis diâmetro do coleto, altura das plantas, número de folhas, área foliar, matéria seca do caule, matéria seca da folha, matéria seca da parte aérea, matéria seca da raiz, matéria seca total e Índice de Qualidade de Dickson (IQD). O substrato S1 (turfa de sphagnum e vermiculita) foi superior aos substratos S2 (casca de pínus e vermiculita), S3 (casca de pínus e fibra de coco) e S4 (solo) em todos os parâmetros avaliados. A análise de componentes principais separou os tratamentos em três grupos de resposta, em que o S1 foi o que exerceu maior influência sobre as variáveis de crescimento, concluindo ser este, dentre os substratos testados, o mais adequado para formação de mudas de mangostão.

Termos para indexação: Garcinia mangostana L., IQD, enraizamento.

${ }^{1}$ Master in Plant Production, Universidade Estadual de Santa Cruz, Ilhéus-BA, Brazil. E-mail: geda almeida@hotmail.com (ORCID 0000-0002-1088-5143)

${ }^{2} \mathrm{PhD}$ in Plant Production, Universidade Estadual de Santa Cruz, Ilhéus-BA, Brazil. E-mail: rafaelapereira2511@gmail.com (ORCID 0000-0002-4677-9502)

${ }^{3}$ Graduating in agronomy, Universidade Estadual de Santa Cruz, Ilhéus-BA, Brazil. E-mail: danillo-js@hotmail.com (ORCID /0000-0003-2791-3371)

${ }^{4} \mathrm{PhD}$ in Plant Production, Adjunct Professor, Universidade Estadual de Santa Cruz, Ilhéus-BA, Brazil. E-mail: gasodre@hotmail. com (ORCID 0000-0003-0711-8637)

${ }^{5} \mathrm{PhD}$ in Plant Biology, Adjunct Professor, Universidade Estadual de Santa Cruz, Ilhéus-BA, Brazil. E-mail: egross@uesc.br (ORCID 0000-0002-1057-0432) 
Mangosteen (Garcinia mangostana L.) belongs to the family Clusiaceae and is a fruitful species with its center of origin in the Malay Archipelago. In Brazil, plantations of this fruit are found in the Amazon region and in the state of Bahia, where the climate is hot and humid, and precipitation well distributed throughout the year. Its fruits have excellent conditions for commercial exploitation, with high market prices (SACRAMENTO et al., 2007; CARVALHO, 2014).

The prolonged nursery time in the system of production of mangosteen seedlings has been considered the main obstacle to the propagation, due to the long time in which the plants remain in this stage, which can reach 24 months. This problem has been attributed to the way germination occurs and the formation of a root system of reduced water and nutrient absorption capacity during the molting phase (CARVALHO, 2014).

Although the system of production of seedlings in controlled environments for various fruit species make use of substrates, which provide nutrients and retains water, there is no standard as to the type of substrate to be used, varying from species to fruit species. The type of substrate, therefore, is a preponderant factor for the development of seedlings and must be adequate and selected to guarantee satisfactory results in the production of quality seedlings (OLIVEIRA et al., 2012).

Substrate for plants is any porous material, used pure or in mixture, which, placed in a container, provides anchorage and sufficient water and oxygen levels for optimal plant development (VENCE, 2008). The use of suitable materials for the formulation of substrates is essential to achieve high quality seedling production. In a system of seedling production the substrate for cultivation should consist of organic material, mineral or the mixture of both. This mixture is considered satisfactory when it presents adequate physical properties of aeration, retention and release of water. However, it is important to note that in the present study, it was found that the presence of high-quality seedlings was associated with a higher quality of seedlings.

In determining the quality of the seedlings, both morphological and physiological characteristics can be used, which are defined internally in the plant. However, the morphological characteristics are more used in the evaluation of the quality of the seedlings due to their greater acceptance by the nurserymen (ELOY et al., 2013).

The morphological characteristics of the seedlings can be evaluated and jointly used to obtain the Dickson quality index (DQI), which is considered as a good indicator of plant growth and development because the robustness and balance of biomass distribution (GOMES et al., 2002). The present study had as objective to evaluate the quality and to relate the growth variables in mangosteen seedlings in response to four different substrate compositions.
The experiment was carried out in a greenhouse on the campus of the Universidade Estadual de Santa Cruz (UESC), from April to December 2017, in the municipality of Ilhéus / Ba. It was used the completely randomized design, where the plants were cultivated in four substrates with ten replicates per treatment.

The following substrates were used: S1 - composed of sphagnum peat and expanded vermiculite $(\mathrm{SP}+\mathrm{EV})$; $\mathrm{S} 2$ - composed of pinus bark and expanded vermiculite $(\mathrm{PB}+\mathrm{EV}) ; \mathrm{S} 3$ - composition of pine bark and coconut fiber $(\mathrm{PB}+\mathrm{CF}) ; \mathrm{S} 4$ - Surface horizon of an Argisol. Data on the electrical conductivity (EC), water retention capacity (CRA), humidity (HU), density (D) and $\mathrm{pH}$ of these four substrates are given in Table 1.

The substrates were enriched with Osmocote ${ }^{\circledR}$ slow release fertilizer $(25 \mathrm{~g})$, Pgmix ${ }^{\circledR}(25 \mathrm{~g})$ and single superphosphate $(100 \mathrm{~g})$ for each $50 \mathrm{~L}$ of the blend. For comparison purposes, the $\mathrm{S} 4$ treatment was considered the reference treatment, since the production of mangosteen seedlings is almost always carried out using soils of the fruit grower's property.

The mangosteen seeds were initially removed from the fruit, washed in running water and then placed to germinate in trays filled with sterilized vermiculite. For planting of the experiment were selected seedlings with approximately $5 \mathrm{~cm}$ in height. At 30 days after germination the seedlings were transplanted into containers with a capacity of $5 \mathrm{dm}^{-3}$ of substrate, with their respective treatment.

The evaluated variables were plant height $(\mathrm{H})$; diameter of the stem (SD); leaf dry mass (LDM); stem dry mass (SDM); shoot dry mass (SHDM); principal root dry mass (PRDM); secondary root dry mass (SRDM); total root dry mass (TRDM); total dry mass (TDM); shoot height: diameter ratio (SHDR), shoot: root ratio (SRR) and quality index of Dickson (DQI).

The diameter of the stem was obtained with a digital caliper and the height, with a millimeter ruler, being taken as standard the shoot apex (apical meristem). The shoot and root system dry mass were quantified by weighing the plant parts after drying at $70^{\circ} \mathrm{C}$ for a period of approximately $72 \mathrm{~h}$. The Dickson Quality Score (DICKSON et al., 1960) was determined by the equation:

$$
\mathrm{DQI}=\frac{\mathrm{TDM}}{\left(\frac{\mathrm{H}}{\mathrm{SD}}\right)+\left(\frac{\mathrm{SHDM}}{\mathrm{RDM}}\right)}
$$

The experimental data were submitted to the Shapiro-Wilk ( $>>0.05)$ and Levene $(p>0.05)$ tests, in order to verify residual normality and homoscedasticity, respectively, and later the analysis of variance was performed. The results of the significant variables studied for analysis of variance were submitted to the Tukey test at $5 \%$ of significance. For the determination of the influence of the treatments on the studied variables, the 
multivariate analysis was also performed through the principal components (PCA).

According to the analysis of variance all the growth variables of mangosteen seedlings at 240 DAP presented differences in response to different substrates (Table 1).

The height and diameter of the stem have a good contribution to evaluate the quality of seedlings, being considered important parameters to estimate the survival of seedlings, as well as the ease of gauging and non-destruction of seedlings (GOMES et al., 2002; OLIVEIRA-JUNIOR et al., 2011; KRATZ, 2011).

In our study the seedlings grown on substrate S1 presented higher mean height than the other treatments, which did not differ among themselves (Table 2). When well managed, after two years of nursery, G. mangostana seedlings reached an average height of $40 \mathrm{~cm}$, being ready for final planting (SACRAMENTO et al., 2007; CARVALHO, 2014). The seedlings formed in substrate S1 at 240 DAP were not fit to go to the field if taken into account the pattern established by the aforementioned authors. However, it should be considered that a shorter nursery time the plants presented on average $75 \%$ of the established standard.

The stem diameter (SD) of the G. mangostana seedlings formed on the substrate $\mathrm{S} 1$ was higher than the other treatments, with a $60 \%$ increase when compared to the plants cultivated in soil (S4).

It is expected that mangosteen seedlings with stem diameter between 9.0 and $12 \mathrm{~mm}$, are usually suitable for definitive planting expected from mangosteen (CARVALHO, 2014). On average, the stem diameter of seedlings $(7.01 \mathrm{~mm})$ developed in $\mathrm{S} 1$ was lower than that established by Carvalho (2014). In spite of this, the performance of the seedlings should be considered promising, due to the values presented by the said author are generally obtained in mangosteen seedlings with approximately 2 years of nursery.

The substrate $\mathrm{S} 1$ presented the best characteristics to stimulate the shoot growth of mangosteen, being superior to the other treatments in the variables LDM, SDM and SHDM. When compared to the substrate S4 (Soil) an average increase of 3.5 times occurred for the SHDM variable. The dry mass of the aerial part indicates the rusticity of a seedling, being that higher values indicate more lignified seedlings with greater capacity of survival in field (GOMES and PAIVA, 2006). Canesin and Barboza (2017), evaluating the quality of passion fruit seedlings concluded the superiority of the commercial substrate composed of peat and vermiculite in all evaluated vegetative parameters when compared to the substrate formed by the mixture of pine bark and vermiculite.

The dry mass of the root system of mangosteen seedlings, values were higher in the plants that grew on the substrate S1. Among the variables related to root formation, PRDM (first order root) did not differ between treatments, while the SRDM (fine roots) of plants produced in $\mathrm{S} 1$ was on average five times higher when compared to substrates S2, S3 and S4. This result can be explained by the differences in the density of the substrates used, where the substrate S1 presented the lowest value (Table 1).

The fact that the density of the substrate is inversely related to the porosity, as the density increases, a restriction to the growth of the roots of the plants may occur, a process called mechanical impedance (KAMPF et al. 1999). According to Allaire et al. (2004) reduced porosity values may cause lack of oxygen for root development. Fermino and Kampf (2006) evaluating the mechanical impedance in substrates concluded that materials with lower dry density may explain the non-occurrence of significant variations when submitted to different water stresses. Pacheco et al. (2015) reported a decrease in root volume and accumulation of biomass in the aerial part of crotolaria plants with increased substrate density, assigning this result to the limitation of penetration of the root system caused by the mechanical pressure of the substrate. Zorbeto et al. (2014) reported a higher density on substrates with pinus bark in their composition.

Robust seedlings with a higher percentage of root emission are better suited to environmental stress conditions guaranteeing higher survival rates in the field. The amount of fine roots in the root system is one of the factors that can interfere in the initial performance of the seedlings in the field, since seedlings that present great production of these roots are more apt to environmental stress conditions, guaranteeing higher rates of survival and initial growth after definitive planting (FREITAS et al., 2005).

The reduced accumulation of biomass by plants grown on substrates S2 and S3 probably resulted from some imbalance in the composition of these substrates. Pinus bark, present in the formulation of substrates S2 and S3, according to Ludwig et al. (2014) reduces the aeration space when associated with other components of different sizes. Coconut fiber, which also composes substrate S3, is a material that should be avoided due to the fact that substrates formulated with this material have inadequate values of total porosity and a low content of available nutrients (DELARMELINA et al. 2014).

The principle of quantitative evaluation consists in the fact that the greater the better the quality changes. However, to avoid distortions such as excessive leaf growth over the root system, quality indexes are used, which are relationships between growth parameters (MARANA et al., 2008).

The SHDR parameter is recognized as one of the main indicators of the quality standard of seedlings and is indicated to determine the survival capacity in the field, with the advantage of being a non-destructive technique. This index should be less than ten to consider with 
adequate standard of quality (BIRCHLER et al., 1998). In the present study, this parameter presented values between 4.57 and 2.15, demonstrating that treatments S1, S2, S3 and $\mathrm{S} 4$ were below the recommended upper limit.

SRR values in the treatments ranged from 3.28 to 5.71, with S1 higher than treatments S2, S3 and S4. The plants grown in the reference treatment (S4) were superior to those grown in S2 and did not differ from the S3 substrate. According to Marana et al. (2008) reasonable SRR values may range from 4.7 to 7.0. These same authors reported that SRR values lower than 4.7 indicate that the seedling did not show a good shoot development. In our study, the G. mangostana seedlings formed on the S1 substrate showed a SRR of 5.71, indicating good SHDM formation. In the substrates S2 (3.87), S3 (3.28) and S4 (4.02) the mean SRR values were lower than those recommended by Marana et al. (2008), indicating that these plants did not present adequate shoot formation.

With respect to DQI, the best result was verified in substrate S1, followed by S3, S4 and S2, being the first one superior to the others (Table 2). In the same way Costa et al. (2012) studying Tamarindus indica reported a relationship between substrate and DQI. Contrasting our results Silva et al. (2018) did not find significant differences for DQI in Achachairu (Garcinia humilis) seedlings grown in different substrate compositions, the authors attributed this result to the adaptability of the seedlings in high quality substrates.

In general, seedlings with higher DQI are more robust and with better distribution of biomass, which allows a great capacity for field development, because they have high vigor (GOMES et al., 2002). According to Caldeira et al. (2012) the higher the DQI, the better the quality of seedlings produced. The evaluation of the quality of the seedlings through the indices and growth variables can also serve as a parameter for the evaluation and identification of the maximum potential of seedling survival after field planting (SILVA et al., 2012).

The relationships between the growth and seedling quality variables and the different substrates can be visualized from the Principal Component Analysis (PCA). The variability of the data was explained in $86.13 \%$ in axis 1 and $9.87 \%$ in axis 2 , totaling $96.0 \%$ of the total variability of the data. (Figure 1). These results were consistent with the criteria proposed by Sneath and Sokal (1973), which suggest that at least $70 \%$ of the total variability of the original data should be explained in the PCA.

In the first principal component, the variables that most influenced growth and quality of G. mangostana seedlings were SDM $(r=0.99)$, LDM $(r=0.99)$, SHDM $(\mathrm{r}=0.99)$, all related to the shoot contribution of plant biomass. The second principal component showed weak correlations between the analyzed variables, except in relation to the variable PRDM (Table 3).

The variables were separated into three response groups, the first encompassing substrate S3 (quadrant 3), which is influencing the PRDM production. The second group includes the substrates S2 and S4 (quadrant 2), which according to PCA had no relation with any of the analyzed variables. The third group was formed by the substrate S1 (quadrant 1), which influenced mainly the production of LDM, SDM, SHDM, SRDM, also influencing the variables SHDR and SRR and DQI, relationships used to evaluate the quality of seedlings.

The results observed in this study indicate that the plants that grew on the substrate S1 presented greater vigor and possibly will be suitable for final planting in less nursery time when compared to the other substrates.

Table 1. Values of electrical conductivity (EC), water retention capacity (WRC), humidity (HU), dry density (D) and $\mathrm{pH}$ of the substrates used in the study.

\begin{tabular}{lccccc} 
Substrate & $\mathrm{EC}\left(\mathrm{mS} \mathrm{m}^{-1}\right)$ & $\mathrm{WRC}(\%)$ & $\mathrm{HU}(\%)$ & $\mathrm{D}\left(\mathrm{kg} \mathrm{m}^{-3}\right)$ & $\mathrm{pH}$ \\
S1 - SP + EV & 600 & 55 & 50 & 145 & 6.5 \\
S2- PB + EV & 700 & 130 & 60 & 290 & 6.3 \\
S3 - PB + CF & 800 & 80 & 55 & 350 & 6.2 \\
S4 - Soil & 1000 & 38 & 45 & 720 & 6.0 \\
\hline
\end{tabular}


SP: Sphagnum peat. VE: Expanded Vermiculite PB: Pinus bark. CF: Coconut fiber
Table 2. Summary of variance analysis of plant height (H), stem diameter (SD), leaf dry mass (LDM), stem dry mass (SDM), shoot dry mass (SHDM), principal root dry mass (PRDM), secondary root dry mass (SRDM), total root dry mass (TRDM), total dry mass (TDM), shoot height: diameter ratio (SHDR), shoot: root ratio (SRR) and quality index of Dickson (DQI) of mangosteen seedlings grown on different substrates at 240 DAP.

\begin{tabular}{|c|c|c|c|c|c|c|c|}
\hline \multirow{2}{*}{ SV } & \multirow{2}{*}{ DF } & \multicolumn{6}{|c|}{ Mean square } \\
\hline & & $\mathrm{H}$ & SD & LDM & SDM & SHDM & PRDM \\
\hline Substrate & 3 & $1184.42 *$ & $19.94 *$ & $297.02 *$ & $19.33^{*}$ & $466.49^{*}$ & $1.64^{*}$ \\
\hline Residue & 36 & 4.98 & 0.2465 & 0.84 & 0.1021 & 1.39 & 0.0431 \\
\hline CV (\%) & & 14.13 & 9.84 & 24.86 & 24.82 & 23.67 & 26.16 \\
\hline SV & DF & SRDM & TRDM & TDM & SHDR & SRR & DQI \\
\hline Substrate & 3 & $3.83^{*}$ & $8.57 *$ & $590.25^{*}$ & $12.39 *$ & $51.45^{*}$ & $3.57^{*}$ \\
\hline Residue & 36 & 0.0601 & 0.1381 & 2.21 & 0.1389 & 0.27 & 0.0442 \\
\hline $\mathrm{VC}(\%)$ & & 31.12 & 26.73 & 23.29 & 12.7 & 17.96 & 23.21 \\
\hline
\end{tabular}

* F Test $(\mathrm{p}<0.05)$. SV: Source of variation; DF: Degree of freedom; VC: Variation coefficient.

Table 3. Average values of plant height (H), stem diameter (SD), leaf dry mass (LDM), stem dry mass (SDM), shoot dry mass (SHDM), principal root dry mass (PRDM), secondary root dry mass (SRDM), total root dry mass (TRDM), total dry mass (TDM), shoot height: diameter ratio (SHDR), shoot: root ratio (SRR) and quality index of Dickson (DQI) of mangosteen seedlings grown on different substrates at 240 DAP.

\begin{tabular}{lcccccc}
\hline Treatment & H $(\mathrm{cm})$ & SD $(\mathrm{mm})$ & LDM $(\mathrm{g})$ & SDM $(\mathrm{g})$ & SHDM $(\mathrm{g})$ & PRDM (g) \\
$\mathrm{S} 1-\mathrm{SP}+\mathrm{EV}$ & $32.05 \mathrm{a}$ & $7.01 \mathrm{a}$ & $11.83 \mathrm{a}$ & $3.35 \mathrm{a}$ & $15.17 \mathrm{a}$ & $1.14 \mathrm{a}$ \\
$\mathrm{S} 2-\mathrm{PB}+\mathrm{EV}$ & $14.05 \mathrm{~b}$ & $3.74 \mathrm{~d}$ & $2.49 \mathrm{~d}$ & $1.81 \mathrm{~d}$ & $4.30 \mathrm{~d}$ & $0.83 \mathrm{~b}$ \\
$\mathrm{~S} 3-\mathrm{PB}+\mathrm{CF}$ & $15.8 \mathrm{~b}$ & $5.03 \mathrm{~b}$ & $2.77 \mathrm{c}$ & $2.12 \mathrm{c}$ & $4.89 \mathrm{~cd}$ & $1.12 \mathrm{a}$ \\
$\mathrm{S} 4-$ Soil & $16.25 \mathrm{~b}$ & $4.4 \mathrm{c}$ & $3.66 \mathrm{~b}$ & $2.42 \mathrm{bc}$ & $6.08 \mathrm{~b}$ & $0.86 \mathrm{~b}$ \\
Treatment & SRDM (g) TRDM (g) & TDM $(\mathrm{g})$ & SHDR & SRR & DQI \\
S1 - SP + EV & $1.52 \mathrm{a}$ & $2.66 \mathrm{a}$ & $17.83 \mathrm{a}$ & $4.57 \mathrm{a}$ & $5.71 \mathrm{a}$ & $1.73 \mathrm{a}$ \\
$\mathrm{S} 2-\mathrm{PB}+\mathrm{EV}$ & $0.28 \mathrm{~b}$ & $1.11 \mathrm{~b}$ & $5.40 \mathrm{c}$ & $3.75 \mathrm{~b}$ & $3.87 \mathrm{~b}$ & $0.71 \mathrm{c}$ \\
$\mathrm{S} 3-\mathrm{PB}+\mathrm{CF}$ & $0.34 \mathrm{~b}$ & $1.49 \mathrm{~b}$ & $6.38 \mathrm{~b}$ & $3.14 \mathrm{c}$ & $3.28 \mathrm{c}$ & $0.99 \mathrm{~b}$ \\
$\mathrm{~S} 4-\mathrm{Soil}$ & $0.65 \mathrm{~b}$ & $1.51 \mathrm{~b}$ & $7.18 \mathrm{~b}$ & $3.69 \mathrm{bc}$ & $4.02 \mathrm{~b}$ & $0.93 \mathrm{~b}$ \\
\hline
\end{tabular}

Means followed by the same letters in the columns do not differ statistically from each other at $5 \%$ probability by the Tukey test. SP: Sphagnum peat. VE: Expanded vermiculite. PB: Pinus bark. CF: Coconut fiber. 


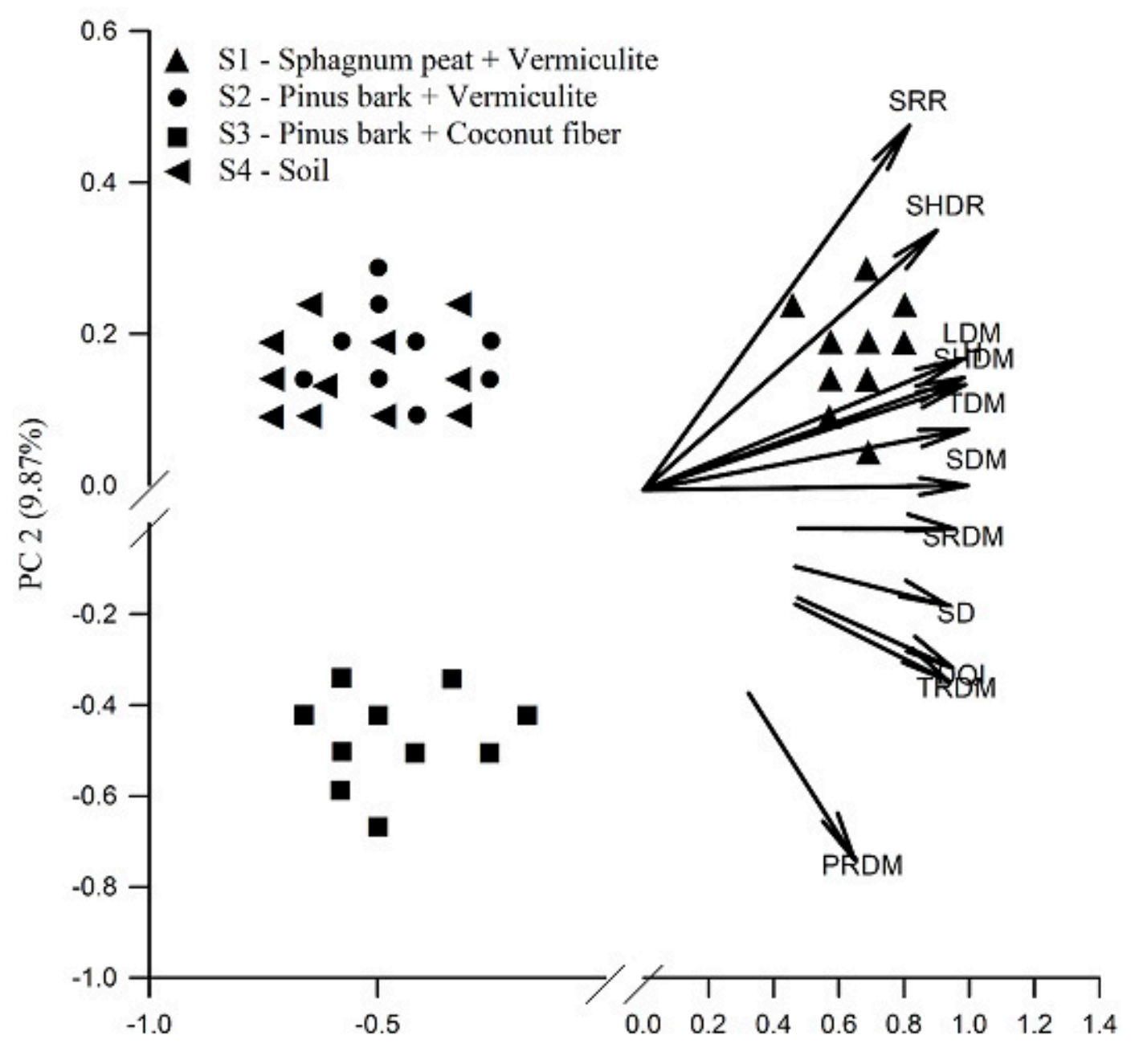

PC $1(86.13 \%)$

Figure 1. Principal component analysis (PCA) of variables plant height $(\mathrm{H})$, stem diameter (SD), leaf dry mass (LDM), stem dry mass (SDM), shoot dry mass (SHDM), principal root dry mass (PRDM), secondary root dry mass (SRDM), total root dry mass (TRDM), total dry mass (TDM), shoot height: diameter ratio (SHDR), shoot: root ratio (SRR) and quality index of Dickson (DQI) of mangosteen seedlings grown on different substrates

at 240 DAP.

Table 4. Pearson correlation coefficients between the principal component scores for the growth and quality variables of mangosteen seedlings at 240 DAP.

\begin{tabular}{ccc}
\hline Variable & PC 1 & PC 2 \\
H & 0.91 & 0.15 \\
SD & 0.93 & -0.17 \\
LDM & 0.99 & 0.17 \\
SDM & 0.99 & 0.01 \\
SHDM & 0.99 & 0.14 \\
PRDM & 0.65 & -0.73 \\
SRDM & 0.96 & 0.00 \\
TRDM & 0.89 & -0.34 \\
TDM & 0.89 & 0.08 \\
SHDR & 0.90 & 0.34 \\
SRR & 0.82 & 0.48 \\
DQI & 0.95 & -0.31 \\
\hline
\end{tabular}

PC - Principal component; H - Plant height; SD - Stem diameter; LDM - Leaf dry mass; SDM - Stem dry mass; SHDM - Shoot dry mass; PRDM - Principal root dry mass; SRDM - Secondary root dry mass; TRDM - Total root dry mass; SHDR - Shoot height: diameter ratio; SRR 


\section{Acknowledgment}

This study was financed in part by the Coordenação de Aperfeiçoamento de Pessoal de Nível Superior Brasil (CAPES) - Financial Code 001.

\section{References}

ALLAIRE, S.; CARON, J.; MÉNARD, C.; DORAIS, $M$. Growing media varying in particle size and shape for greenhouse tomato. Acta Horticulturae, The Hague, v.644, p.307-311, 2004.

BIRCHLER T.; ROSE, R.W.; ROYO, A.; PARDOS, M. La planta ideal: revision del concepto, parametros definitorios e implementaction practica. Investigacion Agraria, Sistemas y Recursos Forestales, Madrid, v.7 n.1-2, p.109-121, 1998.

CALDEIRA, M. V. W.; DELARMELINA, W. M.; LUBE, S. G.; GOMES, D. R.; GONÇALVES, E. O.; ALVES, A. F. Biossólido na composição de substrato para a produção de mudas de Tectona grandis. Revista Floresta, Curitiba, v. 42, n. 1, p. $77-84,2012$.

CANESIN, F.M.; BARBOSA, R. Z. Efeito de diferentes substratos na germinação de sementes de maracujá azedo. Revista Científica Eletrônica de Agronomia, v.31, n.1, p.1-8, 2017. Disponível em: http://faef.revista.inf.br/ imagens arquivos/arquivos destaque/0mNI464UuY1s GE4 2018-1-25-14-42-50.pdf.

CARVALHO, J.E.U. de. Mangostanzeiro: botânica, propagação, cultivo e utilização. Revista Brasileira de Fruticultura, Jaboticabal, v. 36, n.1, p.148-155, 2014.

COSTA, E.; FERREIRA, A.F.A.; SILVA, P.D.L.; NARDELLI, E.M.V. Diferentes composições de substratos e ambientes protegidos na formação de mudas de pé-franco de tamarindeiro. Revista Brasileira de Fruticultura, Jaboticabal, v.34, n.4, p.1189-1198, 2012.

DELARMELINA, W.M.; CALDEIRA, M.V.W.; FARIA, J.C.T.; GONÇALVES, E.DE O.; ROCHA, R.L.F. Diferentes substratos para a produção de mudas de Sesbania virgata, Floresta e Ambiente, Seropédica, v.21, n.2, p.224-233,2014.

DICKSON, A.; LEAF, A.L.; HOSNER, J. Quality appraisal of while spruce and white pine seedling stock in nurseries. Forestry Chronicle, Mattawa, v.36, n.1, p.11-13, 1960.
ELOY, E.; CARON, B.O.; SCHMIDT, D.; BEHLING, A.; SCHWERS, L.; ELLI, E.F. Avaliação da qualidade de mudas de Eucalyptus grandis utilizando parâmetros morfológicos. Floresta, Curitiba, v.43, p.373-384, 2013.

FERMINO, H.; KÄMPF, A. Considerations about the packing density of growing media prepared under increasing levels of humidity. Acta Horticulturae, The Hague, v.697, n.1, p.147-151, 2005.

FREITAS, T.A.S.; BARROSO, D.G.; CARNEIRO, J.G. de A.; PENCHEL FILHO, R.M.; LAMÔNICA, K.R.; FERREIRA, D. de A. Desempenho radicular de mudas de eucalipto produzidas em diferentes recipientes e substratos. Revista Árvore, Viçosa, MG, v.29, p.853861,2005 .

GOMES, J.M.; COUTO, L.; LEITE, H.G.; XAVIER, A.; GARCIA, S.L.R. Parâmetros morfológicos na avaliação da qualidade de mudas de Eucalyptus grandis. Revista Árvore, Viçosa, MG, v.26, n.6, p.655-664, 2002.

GOMES, J.M.; PAIVA, H.N. Viveiros florestais: propagação sexuada. 3.ed. Viçosa: UFV, 2006.

KAMPF A.N.; HAMMER P.A.; KIRK T. Effect the packing density on the mechanical impedance of root media. Acta Horticulturae, The Hague, v.481, n.1, p.689694, 1999.

KAMPF, A. Evolução e perspectivas do crescimento do uso de substratos no Brasil. In: BARBOSA J.G.; MARTINEZ, H.E.P.; PEDROSA, M.W.; SEDIYAMA, M.A.N. (ed). Nutrição e adubação de plantas cultivadas em substrato. Viçosa: UFV, 2004. p.3-10.

KRATZ, D. Substratos renováveis na produção de mudas de Eucalyptus benthamii Maiden et Cambage e Mimosa scabrella Benth. 2011. Dissertação (Mestrado em Ciências Florestais) - Universidade Federal do Paraná, Curitiba, 2011.

LUDWIG, F.; GUERRERO, A. C.; FERNANDES, D. M. Caracterização física e química de substratos formulados com casca de pinus e terra de subsolo. Cultivando Saber, Londrina, v.7, n.2, p.152-162, 2014.

MARANA, J. P.; MIGLIORANZA, E.; FONSECA, E. P.; KAINUMA, R. H. Índices de qualidade e crescimento de mudas de café produzidas em tubetes. Ciência Rural, Santa Maria, v.38, n.1, p.39-45, 2008. 
OLIVEIRA JUNIOR, O. A.; CAIRO, P. A. R.; NOVAES, A. B. Morphophysiological characteristics associated to quality of Eucalyptus urophylla seedlings produced on different substrates. Revista Árvore, Viçosa, MG, v. 35, n. 6, p. 1173-1180, 2011.

OLIVEIRA, K.S.; OLIVEIRA, K.S.; ALOUFA, M.A.I. Influência de substratos na germinação de sementes de Anadenanthera colubrina (Vell.) Brenan em condições de casa de vegetação. Revista Árvore, Viçosa, MG, v.36, n.6, p.1073-1078, 2012.

PACHECO, L.P.; CÓRT SAO MIGUEL, A.S.D.; SILVA, E.M.B.; SOUZA, E.D. de; SILVA, F.D. da. Influence of soil bulk density on shoot and root traits of crotalaria. Pesquisa Agropecuária Tropical, Goiânia, v.45, n.4, p.464-472, 2015.

SACRAMENTO, C.K. do.; COELHO JR, E.; MULLER, C.H.; CARVALHO, J.E.U.; NASCIMENTO, W.M.O. Cultivo de mangostão no Brasil. Revista Brasileira de Fruticultura, Jaboticabal, v.29, n.1, p.197-206, 2007.
SILVA, B.L.B.da; COSTA, E.; SALLES, J.S.; BINOTTI, F. da S.; BENETT, C.G.S. Protected environments and substrates for achachairu seedlings. Engenharia Agrícola, Jaboticabal, v.38, n.3, p.309-318, 2018.

SILVA, R.F. da; SAIDALLES, F.L.F.; KEMERICH, P.D.C.; SWAROWSKY, A.; SILVA, A.S.da. Crescimento e qualidade de mudas de Timbó e Dedaleiro cultivadas em solo contaminado por cobre. Revista Brasileira de Engenharia Agrícola e Ambiental, Campina Grande, v.16, n.8, p.881-886, 2012.

SNEATH, P. H.; SOKAL, R. R. Numerical taxonomy: rhe principles and practice of numerical classification. San Francisco: W.H. Freeman, 1973. 573p.

VENCE, L.B. Disponibilidad de agua-aire en sustratos para plantas. Ciencia del Suelo, La Plata, v.26, p.105$114,2008$.

ZORZETO, T.Q.; DECHEN, S.C.F.; ABREU, M.F de; FERNANDES JÚNIOR, F. Caracterização física de substratos para plantas. Bragantia, Campinas, v.73, n.3, p.300-311, 2014. 